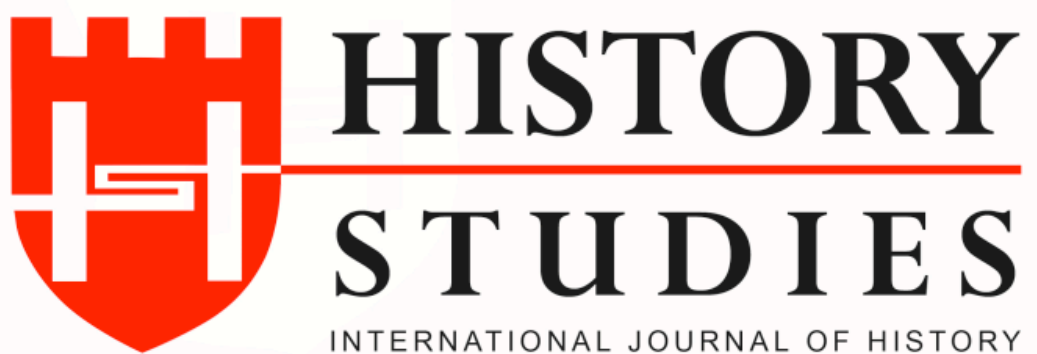

ISSN: 13094173 (Online) 1309 - 4688 (Print)

Volume 11 Issue 5, October 2019

DOI Number: 10.9737/hist.2019.789

Araştırma Makalesi

Makalenin Geliş Tarihi: 30.05.2019 Kabul Tarihi: 17.09.2019

Atıf Künyesi: Tolga Uzun, "Sivas Yıldızeli Şeyh Halil Türbesi Duvar Resimleri”, History Studies, 11/5, Ekim 2019, s. 1839-1853.

\title{
Sivas Yuldızeli Şeyh Halil Türbesi Duvar Resimleri
}

Wall Paintings in The Tomb of Sheikh Khalil in Sivas

\author{
Dr. Tolga Uzun \\ ORCID: 0000-0003-4665-5726
}

Karabük Üniversitesi

\begin{abstract}
Öz: Osmanlı Mimarisinde 18. yüzyıldan itibaren batı etkisiyle görülmeye başlayan duvar resimleri, 19. yüzyıl boyunca imparatorluğun tüm bölgelerine yayılmıştır. Sivil ve dini mimarinin hemen hemen tüm yapı türlerinde görülen bu uygulama, üslup özellikleri bakımından batılı formları izlerken konu bakımından bulundukları yapı tiplerine göre değişiklik gösterirler. Özellikle dini yapılarda gördüğümüz kimi özgün tasvirler barındırdıkları ikonografik anlamlar ile ilgi çekicidir. Devrinin sosyal, dini, politik ve teknolojik olaylarına gönderme yapan bu tasvirlerin kamuya açik yapı türlerinde yer almaları toplumsal niteliği olan olayların görsel dille yayılmasını ve paylaşılmasını amaçlıyor olmalıdırlar. Bu çalışma, bir yandan Sivas'ın Yıldızeli ilçesi Şeyh Halil Köyü’nde bulunan Seyh Halil Türbesi'nin duvar resimlerini tanıtmayı amaçlarken öte yandan bu resimlerin bugün hakkıyla anlamlandıramadığımız kodlarına devrin politik, dini ve sosyal yapısının içerisinde düşünerek çözüm önerileri sunmayı amaçlamaktadır.
\end{abstract}

\begin{abstract}
Anahtar Kelimeler: Sivas, Yıldızeli, Şeyh Halil Türbesi, Duvar Resimleri, İkonografi.
Abstract: Wall paintings, seen in Ottoman architecture from the 18. century by the effect of Western World, was spread to whole Empire area in the 19. century. This application could be seen all samples of civilian and religious architecture. Although they resemble Western World style with regard to the wording, they may change according to the subject with regard to the building types. Some original descriptions, which especially could be seen in the religious buildings, are interesting with regard to iconographic meanings. These descriptions have reflected social, religious, political and technological aspects of the period. Since these descriptions are in the buildings which are open everybody, it may be thought that aim of them must be to spread and share the social events with visible instruments. This article is about wall paintings of wall paintings in the tomb of Sheikh Khalil in Yıldizeli, Sivas. Our aim is to train to solve the codes of them and to bring some proposals about them.
\end{abstract}

Keywords: Sivas, Yıldızeli, Şeyh Halil Tomb, Wall Paintings, Iconography.

\section{Giriş}

Osmanlı imparatorluğunun 18.yüzyıl başlarından itibaren Avrupa ülkeleri ile kurduğu ilişkiler, mimarlık alanında büyük değişiklik/yeniliklere yol açmıştır. Yapıların duvarlarına yapılan resimler ve kalem işi bezemeler bu yenilikler arasında önemli bir yer tutar. Sarayın öncülük ettiği bu yeni tür önce başkent İstanbul'da ki seçkinlerin konaklarına daha sonra imparatorluğun tüm bölgelerine 19. yüzyıl boyunca yayılmıştır. Anadolu'da Ayan ve eşraftan kimselerin konaklarının yanı sıra cami, türbe ve şadırvan gibi dini mahiyetteki yapı türlerinde de görülen duvar resimlerinin konularını natürmort, manzara, dini/sembolik, günlük yaşam ve endüstri devriminin Osmanlıya yansımasını canlandıran araç gereçleri simgeleyen betimlemeler oluşturmaktadır. 
Genellikle, C ve S kıvrımlı barok-rokoko unsurlardan oluşan batılı formların çevrelediği kartuşlar içerisine yapılan bu resimler ilginç bir şekilde yüzyıllarca Osmanlı sarayının benimsediği resimli el yazmalarının konu repertuarını devam ettirmezler. Anadolu, Balkanlar ve Orta Doğu gibi imparatorluğun başkent dışında kalan bölgelerinde muhtemelen gezgin sanatçılar tarafindan yapılan bu resimler kimi zaman başkent örneklerine öykünürken kimi zaman ise yapıldığı coğrafyanın sosyal, kültürel ve dinsel eğilimlerine göre değişiklik göstermiştir.

Yapılan çalışmalar sayesinde 18. ve 19. yüzyıla ait Osmanlı duvar resimleri bilim dünyasına tanıtılmış gerek üslup ve gerekse ikonografik açıdan değerlendirilmiştir. Kuşkusuz bu çalışmalar Rüçhan Arık'ın (1976) ve Günsel Renda'nın (1977) çalışmaları ile derli toplu ve kapsamlı olarak ele alınmıştır. Resimler üzerindeki üslup ve ikonografik çalışmalar günümüzde de devam etmektedir ancak kimi sembolik tasvirlerin taşıdıkları anlamlar ve kodlar yeterince açıklığa kavuşmuş değildir. Bu konuda yapılan yayınlar kısıtlı olmak ile birlikte özellikle Baha Tanman'ın (1993) ve Nurhan Atasoy'un (2006) çalışmaları tasavvuf sembolizmi konularında önemli ve yol gösterici çalışmalardır.

Halk arasındaki inanışa göre Horasan kökenli bir Selçuklu beyi olan Şeyh Halil, Rumlarla yapılan savaşta başı kesilmiş ancak o başını yerden alarak bugün türbenin bulunduğu yere kadar getirerek şehit olmuştur. ${ }^{1}$ Türbe, Şeyh Halil, eşi ve çocuklarına ait beş sandukayı barındırmakta ve yöre halkından askere gidecek olan gençler, burayı ziyaret ederek iki rekat namaz k1lıp, türbedeki örtülerden bir parça keserek ziyaretlerini tamamlamaktadırlar ${ }^{2}$

Sivas'ın Yıldızeli ilçesi, Şeyh Halil beldesinde yer alan türbenin tarihi ile ilgili bir kayıt yer almamakla birlikte, mihrap nişinin batısında okunan 1275 (m.1858) tarihi yapının bu tarihte bir onarım geçirdiği ve duvar resimlerinin de bu onarım sırasında yapıldığını düşündürmektedir. ${ }^{3}$ (Harita 1). Türbe, kare planlı olup, tromp geçişli sekizgen kasnaklı bir kubbe ile örtülmüştür. Duvarlar, dışarıdan düzgün kesme taş ile kaplanmıştır. Doğu cephesinde basık kemerli bir giriş kapısı ve kapının üzerinde mazgal formlu bir pencere açıklığı yer almaktadır. Diğer cephelerde de pencere açıklıkları bulunmakla birlikte bunlar kapı üzerindekine nazaran daha alçak yapılmış olup yine mazgal formu korudukları görülmektedir (Resim-1).

\footnotetext{
1 Yaşar Kalafat, "Diyanet İşleri Başkanlığı Arşivine Göre Horasan Eri Olarak Bilinen Anadolu Yatırları I", Ankara Üniversitesi Illahiyat Fakültesi Dergisi, C.40, 1966, s.523.

${ }^{2}$ Doğan Kaya, "Sivas'ta Yatmakta Olan Horasan Merkezli Anadolu Erleri”. Halkbilim Araştırmaları. Kitapevi Yayınları, İstanbul, s.261-285.

${ }^{3}$ Hakkı Acun, "Sivas ve Çevresindeki Eski Eserlerin Listesi ve Turistik Değerleri”, Vakıflar Dergisi, C.20, 1988, s.200.
} 


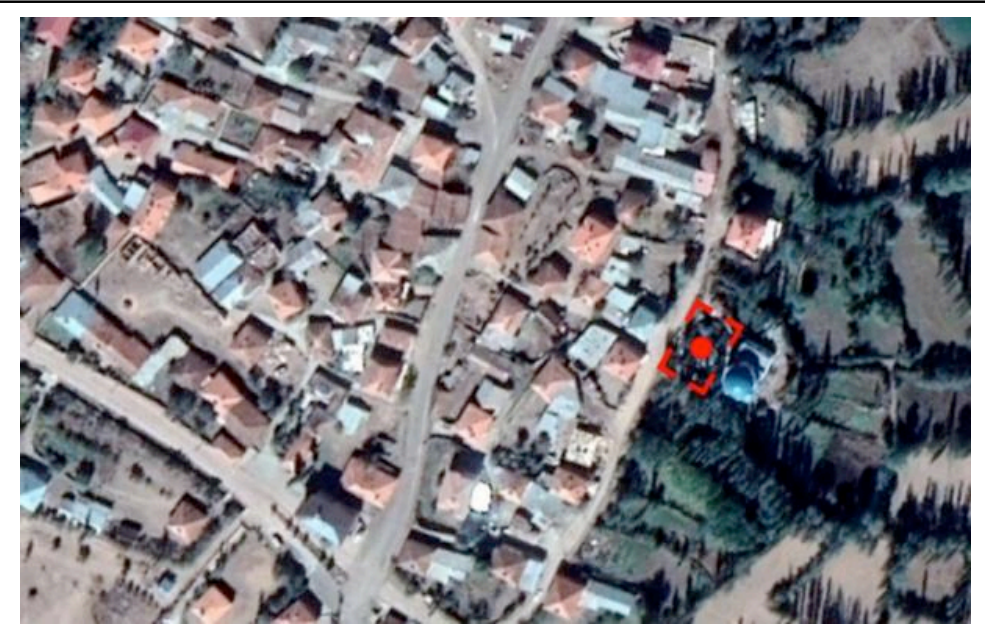

Harita 1: Sivas, Yıldızeli Şeyh Halil Türbesi (3950'46" N 3608'22" E)
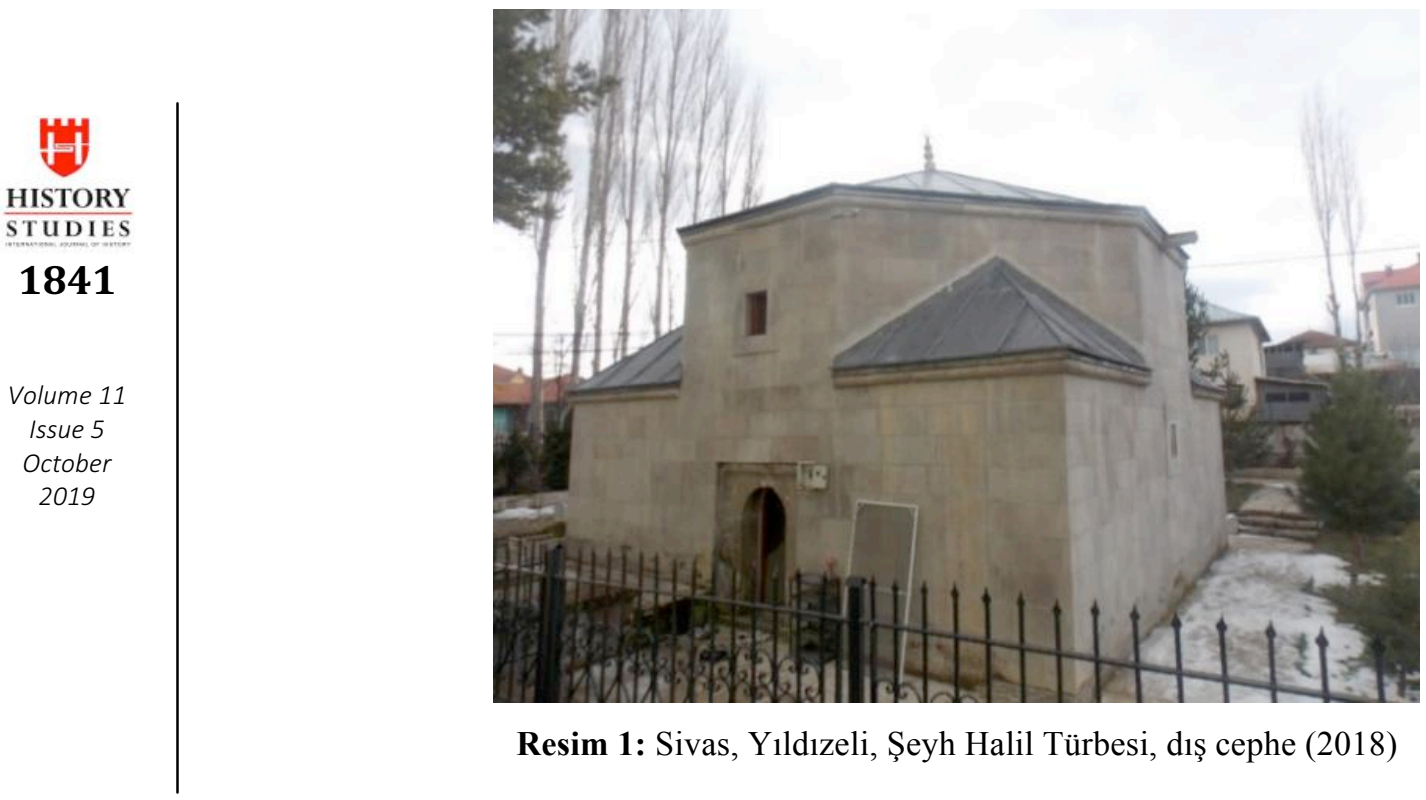

Resim 1: Sivas, Yıldızeli, Şeyh Halil Türbesi, dış cephe (2018)

Türbenin duvar resimleri, yapıldığı dönemin çağdaşı örnekleri ile üslup ve konu açısından benzerlik taşımaktadır. Muhtemelen gezgin sanatçılar tarafından yapılan bu resimlerin barındırdığı ikonografik anlamlar döneminin siyasi, kültürel, dini ve tasavvufi kodlarını da bünyesinde taşımaktadır. Türbenin iç yüzeylerinde bulunan tasvirlerin bir kısmı çağdaşı birçok yapıda karşılaştığımız türden olmakla birlikte kimi tasvirler ise içerdiği sembolik kodlar dolayısıyla bugün yeterince çözümlenememiştir. Özellikle güney duvarında gördüğümüz Mevlevi ve Bektaşi başlıklarının bir arada bulunuşu böyle ilginç bir örneği oluşturmaktadır. Bu çalışma bir yandan türbenin duvar resimleri tanıtmayı amaçlarken bir yandan ise kimi sembolik tasvirlerin yapıldığı dönemde hangi kültürel, siyasi ve sosyolojik kaygılar ile yapıldığına dair çözüm önerileri sunmayı amaçlamaktadır.

\section{Duvar Resimleri}

Türbenin iç duvar yüzeylerinde yoğun bir resim programı görülür. Bu resimler dönemin tüm konu türlerini yansıtır şekilde, manzara, mimari ve natüralist kompozisyonlardan oluşur.

\section{History Studies}


Bununla birlikte sembolik tasvirler olarak nitelendirdiğimiz ve genellikle dini yapılarda görülen tarikatlara ait birtakım semboller resim programının diğer unsurlarıdır. Resimler genellikle pencere hizasındaki duvar boşluklarına yapılmış olup, yapıda geçiş elemanı olarak kullanılan trompların yüzeyinde de resimler olduğu ancak çeşitli tahribatlar neticesinde kaybolduğu boya kalıntılarından anlaşılmaktadır. Bunlardan yalnızca güneybatı trompundaki kompozisyon günümüze gelebilmiştir.

Giriş kapısının bulunduğu doğu yönündeki duvardan başlayarak sağa doğru sırasıyla kompozisyonlar şöyle sıralanabilir:

\subsection{Doğu Duvarı Yüzeyindeki Duvar Resimleri}

Doğu yönündeki giriş kapısının üzerini " $S$ " ve " $C$ " kıvrımlı natüralist çiçeklerin ve çiçek girlandların oluşturduğu bir kompozisyon çevrelemektedir. Kapının solunda geniş gövdeli, dar ağızlı, kulplu ve mavi renkteki kâse içerisine yerleştirilmiş dalları ve yaprakları mavi, çiçekleri kiremit kırmızı olan çiçek tasviri ve yanında yine mavi renkte kapaklı bir ibrik dikkat çekmektedir. Sağda ise, bir sehpa üzerinde pembe ve sarı renklerden oluşan cinsi anlaşılamayan çiçek demeti alttan üste doğru daralan bir kompozisyonla yüzeyi doldurmaktadır. Yazı bezemesi olarak, beyaz zemin üzerine siyah harflerle birer dairesel madalyon içerisinde karşılıklı olarak "Osman" ve "Ebubekir" yazıları görülmektedir. Yazı panolarının etrafı bir taç oluşturulacak şekilde yoğun bitkisel yapraklar ve çiçekler ile bezeli olup (Resim 2) köşelerdeki tromp yüzeyi bezemeleri, sıvaların kabarıp dökülmesiyle büyük ölçüde günümüze gelememiş ve tahrip olmuştur.

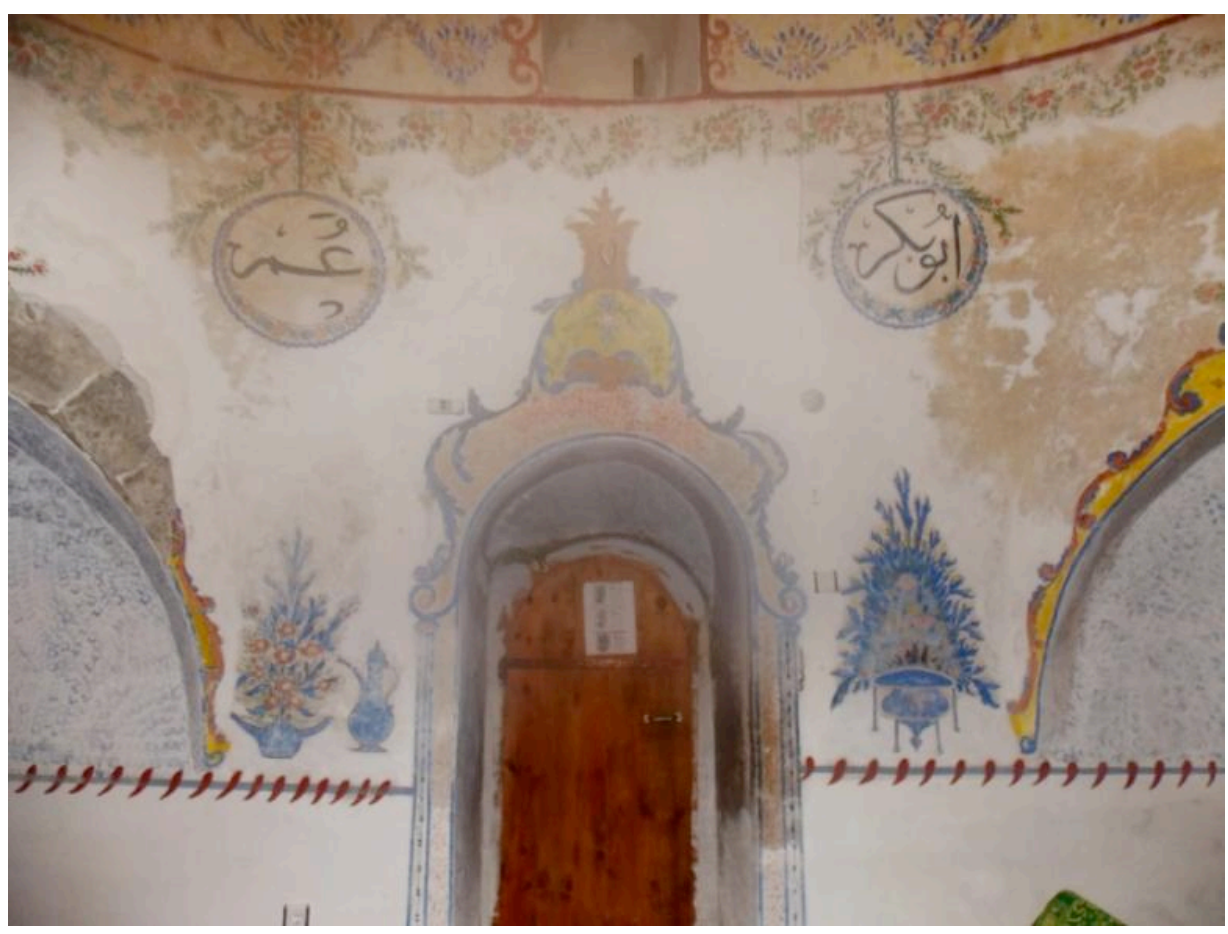

Resim 2: Sivas, Yıldızeli, Şeyh Halil Türbesi, doğu cephesi (2018) 


\subsection{Kuzey Duvarı Yüzeyindeki Duvar Resimleri}

Türbenin kuzey duvarında bulunan mazgal formlu pencere, kaide üzerinde yükselen silindirik biçimli sütunun taşıdığı yuvarlak kemerle çevrelenmektedir (Resim 3). Pencerenin sağ yanındaki dikdörtgen bir pano içerisinde ağaç kompozisyonu yer almaktadır. Bu panoyu bitkisel bezemelerle tıpkı bir çatı görünümüyle ele alınarak cami görünümü verilmeye çalışılmıştır. Sol yanında ise yine bir çerçeve içerisine kasnak üzerine oturtulmuş tek kubbeli, iki minareli bir cami tasviri betimlenmiştir. Minareler küçük âlemler ile taçlandırılmıştır. Caminin hemen altında bir şadırvan yer almaktadır. Resmin ön planında ise geleneksel peyzaj tasarımının vazgeçilmez öğeleri olan servilerden ve çınarı andıran ağaçlardan oluşmaktadır (Resim 4). Yazı bezemesi olarak beyaz zemin üzerine siyah harflerle birer dairesel madalyon içerisinde karşılıklı olarak "Ali" ve "Fatıma" yazıları bulunmaktadır. Öyle ki, sol taraftaki Ali yazısının yanında Hz. Ali’nin kılıcı olarak bildiğimiz zülfikar betimlemesi dikkat çekmektedir. Mavi renkteki zülfikar, tromplarla aynı renkte olup bir uyum içerisinde ele alınmaktadır (Resim 5). Her iki yönde geçiş elemanı olan trompların duvar yüzeyleri tahrip olduğundan günümüze ulaşamamıştır.

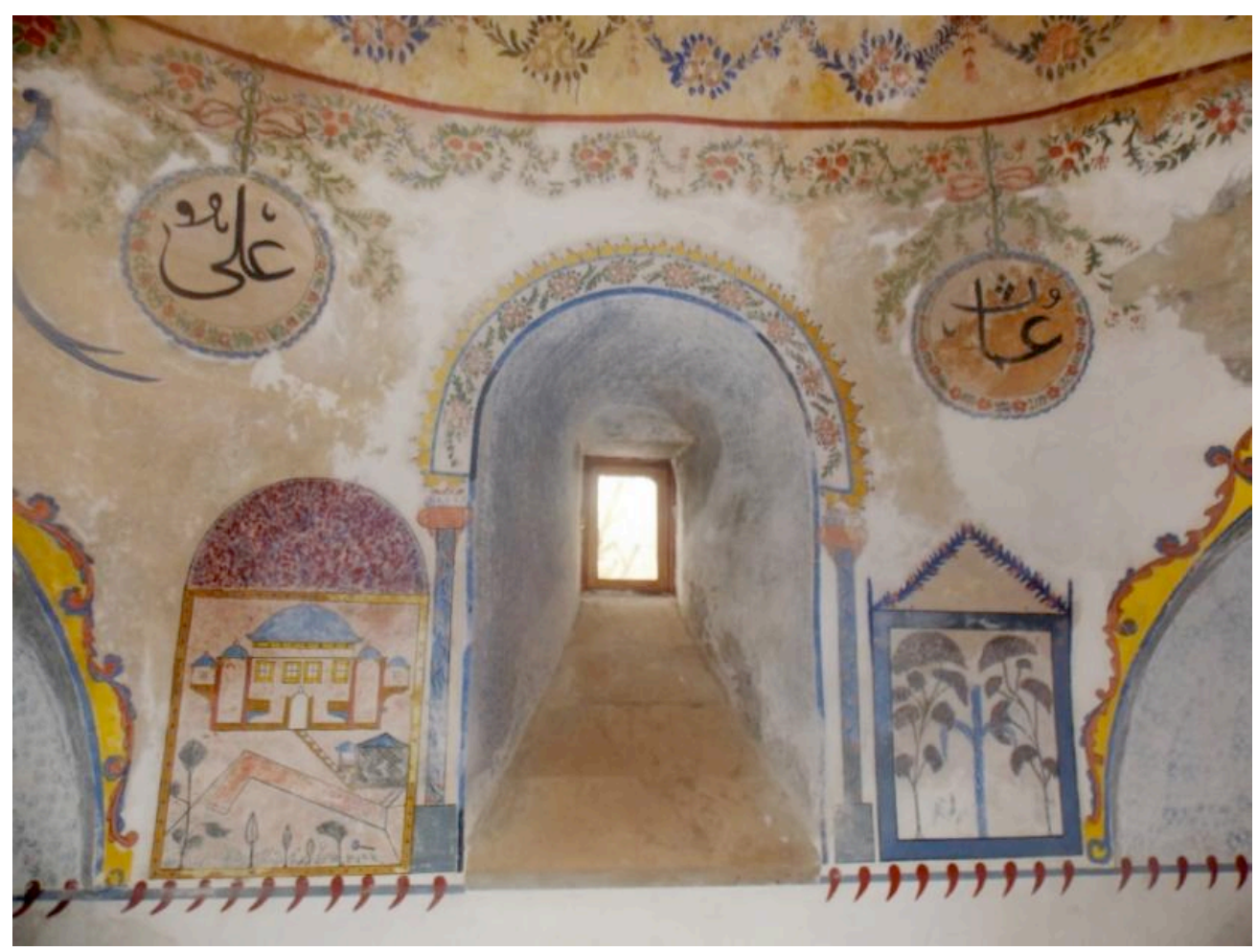

Resim 3: Sivas, Yıldızeli, Şeyh Halil Türbesi, kuzey cephesi (2018) 


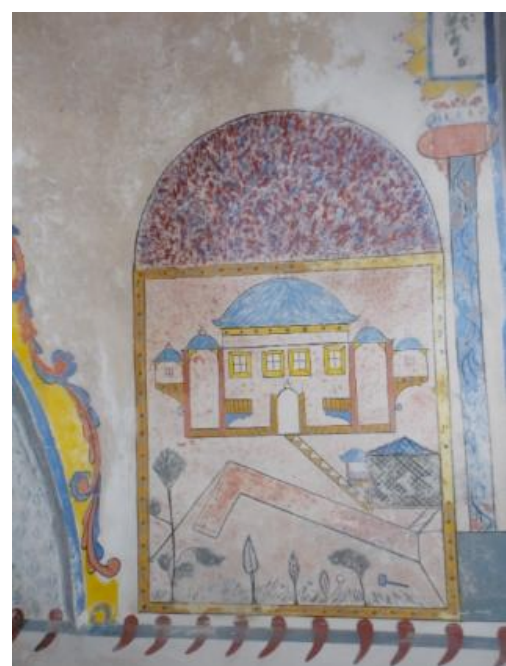

Resim 4: Sivas, Yıldızeli, Şeyh Halil Türbesi, kuzey cephesinde cami tasviri (2018)

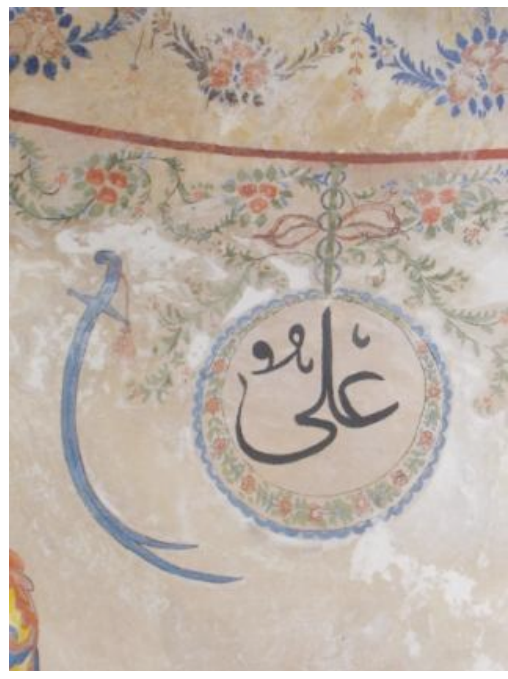

Resim 5: Sivas, Yıldızeli, Şeyh Halil Türbesi, kuzey cephesinde Zülfikar (2018)

\subsection{Batı Duvarı ve Güneybatı Tromp Yüzeyindeki Duvar Resimleri}

Batı duvarında da diğer duvar yüzeylerinde karşılaştığımız ortadaki mazgal formlu pencerenin iki yanında vazo içinden çıkan çiçek motifleri tekrarlanmaktadır. Soldaki, dar boyunlu ve dar ağızlı mavi renkli bir kâse içine yerleştirilmiş dal ve yaprakları mavi, çiçekleri yeşilimsi olan bir narçiçeği tasviri bulunmaktadır. Vazonun kaide bölümü tahrip olmuştur. Sağdaki ise, geniş gövdeli ve geniş ağızlı sarı saksıdan yükselen beyaz renkli cinsi anlaşılamayan çiçekler bulunmaktadır. Çiçekler, alttan üstte doğru daralan bir kompozisyonla yüzeyi doldurulmuştur. $\mathrm{Bu}$ çiçek demetlerinin hemen üzerinde beyaz zemin üzerine bitkisel süslemelerle çevrelenmiş dairesel madalyonlar içerisine karşılıklı olarak "Hasan" ve "Hüseyin" yazıları yer almaktadır (Resim 6). 


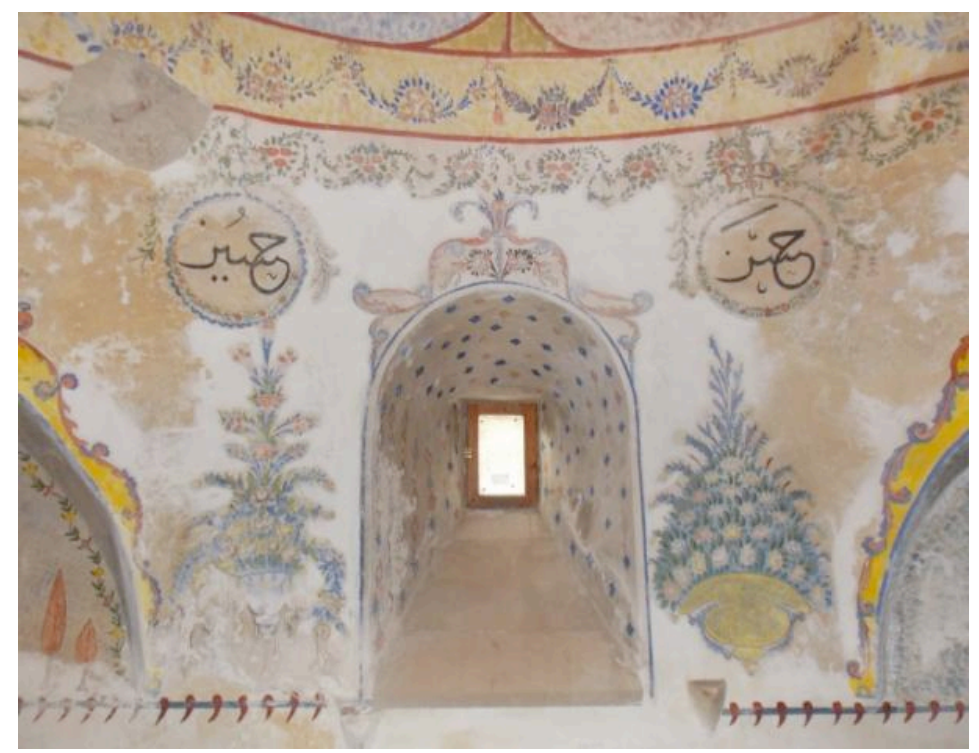

Resim 6: Sivas, Yıldızeli, Şeyh Halil Türbesi, batı cephesi (2018)

HISTORY STUDIES

1845

Volume 11

Issue 5

October

2019

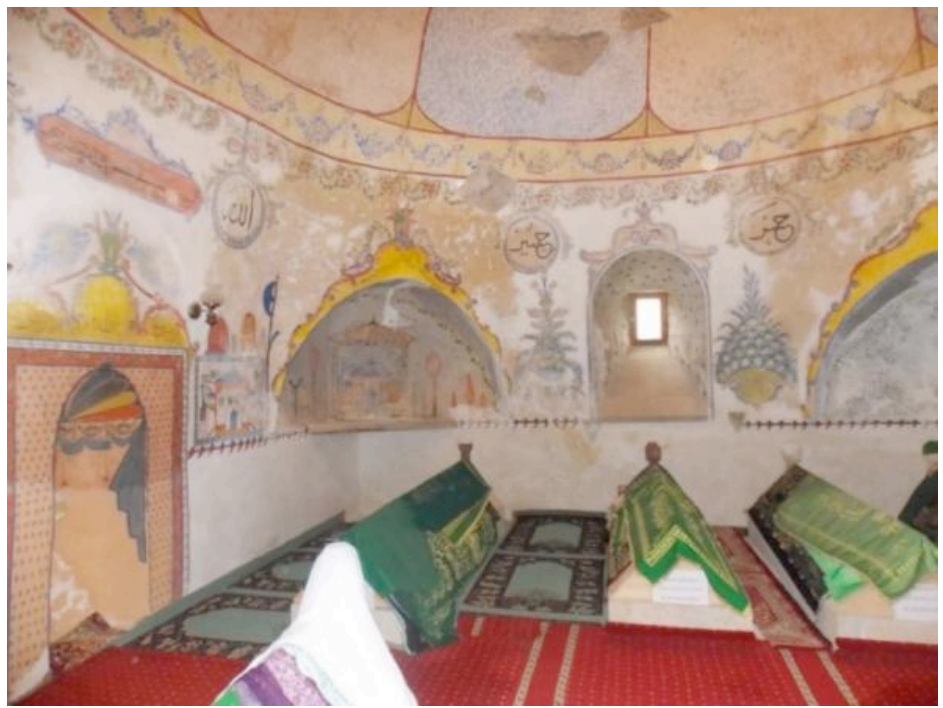

Resim 7: Sivas, Yıldızeli, Şeyh Halil Türbesi, güneybatı köşesindeki tromp (2018)

Güneybatıdaki trompun içinde tek katlı, tek kubbeli, iki pencere açıklığı ve ortada bir kapı açıklığı ile betimlenmiş bir türbe tasviri yer almaktadır. Yapı etrafını çevreleyen kahverengi çatılı baldeken türbe yapısının içine yerleştirilmiştir. Mavi renkli kubbenin örttüğü yapının

\section{History Studies}


sağında ve solunda görülen köşe kuleleri yine mavi renkteki küçük kubbelerle örtülmüştür. Türbe tasvirinin sağında ve solunda üzerine eğilen mavi renkli ağaçların yanı sıra soldan sağa siyah bir muin, muine asılı bir kamberiye ve beyaz renkli bir Bektaşi tacının yer aldığı tekke ve tarikat sembolleri görülür. Trompun iç kısmında bunlardan başka üsluplaştırılmış servi ağaçları ve adlandıramadığımız bir nesne tasvir edilerek tromp bitkisel bezemeyle çevrelenerek sonlandırılmıştır (Resim 8).

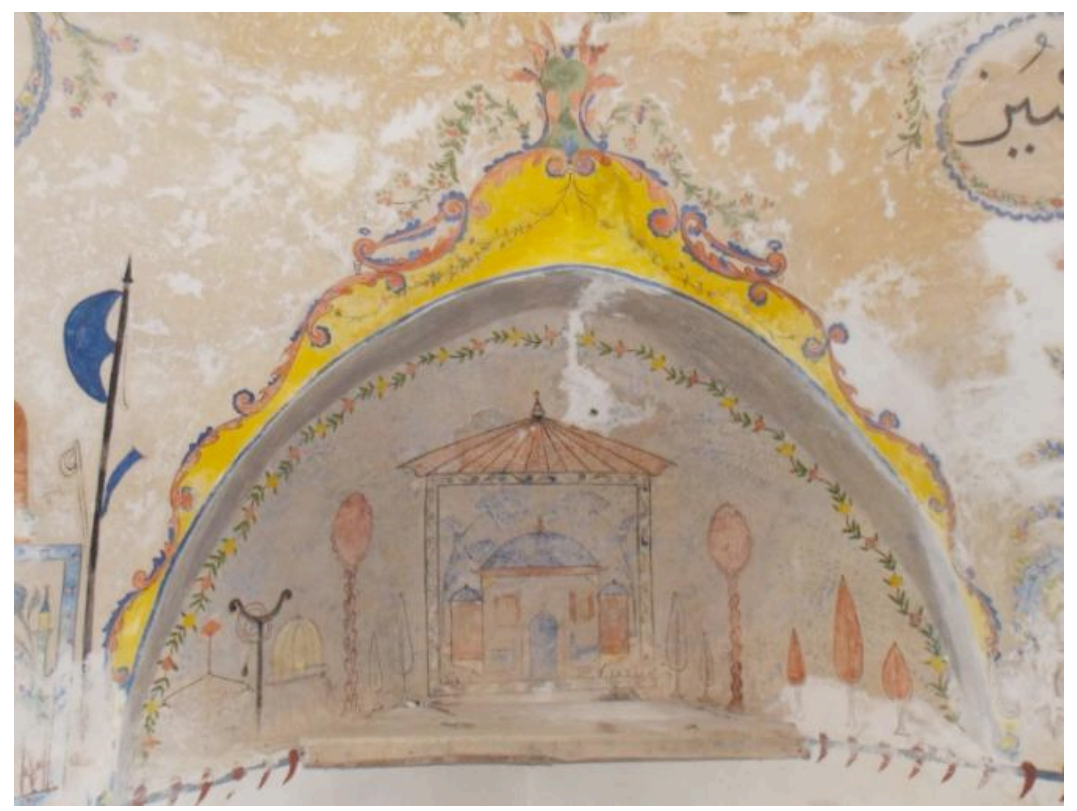

Resim 8: Sivas, Yıldızeli, Şeyh Halil Türbesi, güneybatı köşesindeki tromp; türbe tasviri ve tarikat sembolleri (2018)

\subsection{Güney Duvarı Yüzeyindeki Duvar Resimleri}

Mihrabın yer aldığı güney duvarının üst kısmında karşılıklı olarak etrafında taç oluşturacak biçimde yoğun bitki yaprakları ve çiçeklerle bezeli birer dairesel madalyon içesinde "Allah" ve "Muhammed" yazıları yer almaktadır. Bu madalyonların arasında çerçeve içinde ve kahverengi zemin üzerine "Bismillahirrahmanirrahim" yazısı okunur (Resim 9). Bu yazı dizisinin altında yer alan mihrabın tepelik kısmında sarı zemin üzerine yapılmış " $S$ " ve " $C$ " kıvrımları oluşturan, kahverengi bitkisel motiflere yer verilmiștir. Bu bölümün içerisinde sağdan sola doğru " $Y a$ Fettah 1275", "Ya Allah" ve "Ya Rezzak" şeklinde Allah'ın Esma-ül Hüsna'dan isimleri yer alır. Burada görülen h.1275/m.1858-59 tarihi duvar resimlerinin tarihi olmalıdır (Resim 10). Mihrap ise mavi şeritler ile sınırlanan ve iç kısmı bitkisel bezemeler ile doldurulmuş üç pano şeklinde tasarlanmış olup mihrap nişinin üst kısmı mavi, turuncu ve sarı renklerin kullanıldığ 1 bir istiridye motifi ile sonlanmıştır. Anadolu'da cami mihraplarında sıkça rastladığımız perde ve yukarıdan sarkan kandil motifi bu türbenin mihrabında da yer almıştır. 


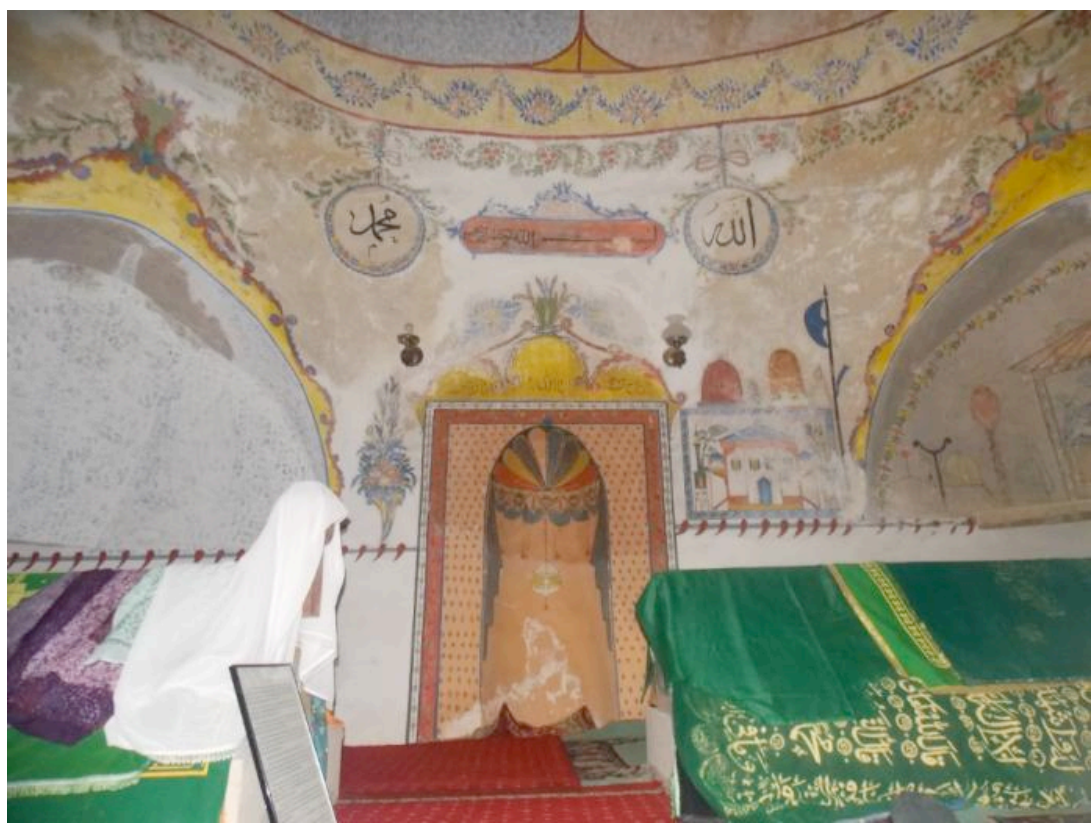

Resim 9: Sivas, Yıldızeli, Şeyh Halil Türbesi, güney cephesi (2018)

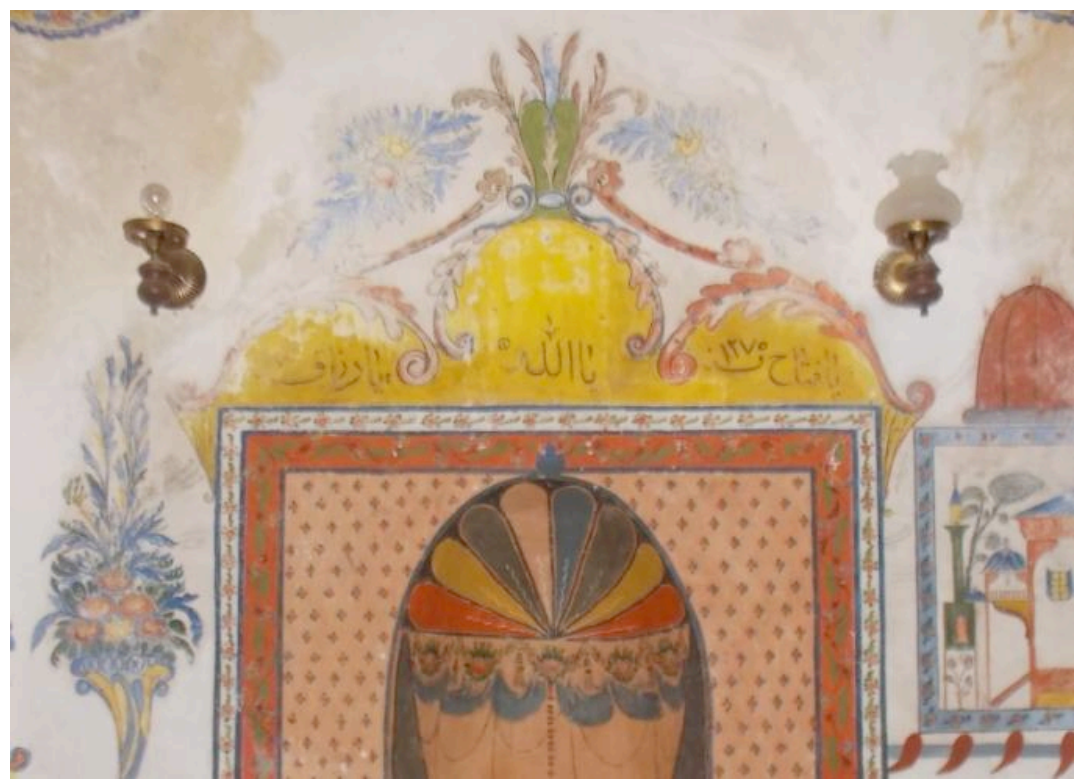

Resim 10: Sivas, Yıldızeli, Şeyh Halil Türbesi, güney cephesi yazı bezeme (2018)

Mihrabın solunda mavi yapraklı bir çiçek demeti, sağında ise bitkisel bezemeli dikdörtgen bir pano içerinde yine mavi renkte tek kubbeli, iki minareli bir cami tasviri betimlenmiştir. Camiyi çevreleyen dikdörtgen panonun üzerinde tarikatlara ait birtakım semboller bulunmaktadır. Solda Bektaşilerin on iki imamı temsil ettiğini gösteren on iki dilimli Bektaşi tacı ve hemen sağında ise yukarıya doğru hafifçe daralan ve tepesinin yuvarlak olduğu Mevlevi sikkesi yer almaktadır (Resim 11). İki tarikata ait başlıklarının bir arada bulunması oldukça dikkat çekicidir. Panonun hemen sağında da sapı uzun başı demir temrenli savaş aleti olan teber yer almaktadır. Bu tasvirlerin hepsi gezici dervişlerin yanında taşıdıkları eşyalardır.

\section{History Studies}




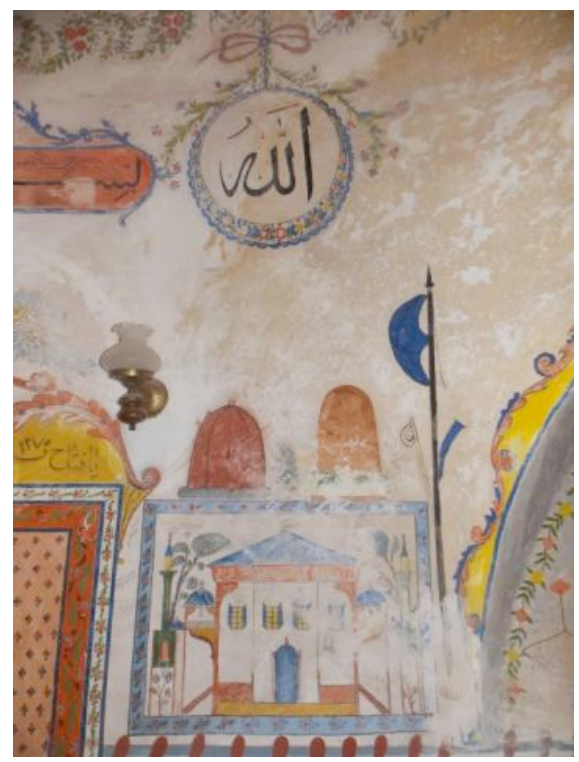

Resim 11: Sivas, Yıldızeli, Şeyh Halil Türbesi, güney cephesindeki cami tasviri ve tarikat sembolleri (2018)

Türbede, kompozisyonlar tüm cephelerde görülürken kubbede de yer almıştır. Duvar üzerine oturan kubbe ortadan bir şemsiye gibi açılan kaburgalarla sekiz dilime ayrılmıştır. (Resim 12). Her bir dilim dönüşümlü olarak açık kiremit kırmızı ve açık mavi ile boyanarak kubbe eteğinde çiçek demetleri ile doldurulmuş bir kuşak ile sonlanmaktadır. Kubbenin göbeğinde dışta sekiz köşeli yıldız, içte ise daire şeklinde çeşitli bitkisel bezemeler yer alır.

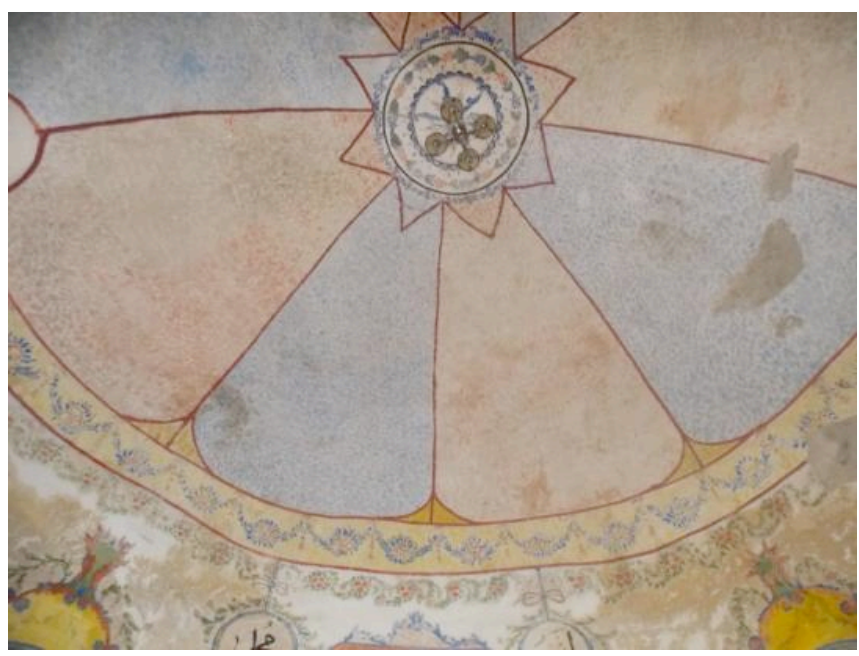

Resim 12: Sivas, Yıldızeli, Şeyh Halil Türbesi, kubbe (2018) 


\section{2.İkonografik Değerlendirme}

19. yüzyılın duvar resimli birçok yapısında karşılaştı̆̆ımız bitkisel, mimari, sembolik tasvirler Şeyh Halil türbesinin duvar resimlerinde de görülür. Batı etkisinin Osmanlı mimari bezemelerine yansıması büyük oranda bitki yaprakları ve çiçek bezemeleriyle olmuştur. Öyle ki vazo içerisinden çıkan çiçek tasvirleri bu dönemin bir sembolü haline dönüşmüştür. Yapının duvarlarında pek çok bitkisel bezeme ve çiçek tasviri olmasına karşın belki batı duvarında rastladığımız ve narçiçeğine benzeyen tasvirinin ikonografik anlamı üzerinde durulabilir çünkü nar ve narçiçeği İslam dininde özellikle Kur'an-1 Kerim'de; “Allah'ın yarattığı güzelliklerin bir örneği" ve "cennet meyvesi" olarak anılır (En'am Suresi: 99. ve 141. Ayet ve Rahman suresi 68. Ayet). Türk süsleme sanatlarında oldukça geniş bir kulanım alanı ve çeşitlemeleri bulunan bu bitkinin tılsımlı, koruyucu, ölümsüzlük, bolluk ve bereket gibi anlamları da bulunmaktadır. ${ }^{4}$

Mimari tasvirler:Yapının güneybatı trompunda rastladığımız baldaken türbe tasviri, düzenlenişi açısından ya içinde bulunduğu türbenin ya da aynı geleneğe sahip daha üst makamda bulunan bir şeyhin türbesinin tasviri olabileceğini düşündürür. Anadolu'da bu tip baldaken türbe tasvirini Kastamonu-Pınarbaşı- Savaş Köyü Tekke Camii, Aydın Soma Hızır Bey Camii, Tokat Zile Tekke Köyü Şeyh Nusrettin Türbesi, Tokat Yeşilce Köyü Şeyh Eyük Türbesi, Amasya II. Beyazıd Camisi Şadırvanı kubbe eteğinde de görürüz (Resim 13-14). R.Arık; Amasya Merzifon Kara Mustafa Paşa Cami Şadırvanı'nda gördüğü baldaken türbe tasviri için "Merzifon'daki yaşlılar bunun Seyyid Ahmed Rufai'yi sembolize ettiğini söylediklerini”" ifade etmektedir. ${ }^{5}$ Ancak Şeyh Halil Türbesi içindeki baldeken türbenin içerisinde bir türbe betimlemesinin daha olması Anadolu'daki benzer örnekler içinde ayırt edicidir.

Volume 11

Issue 5

October

2019

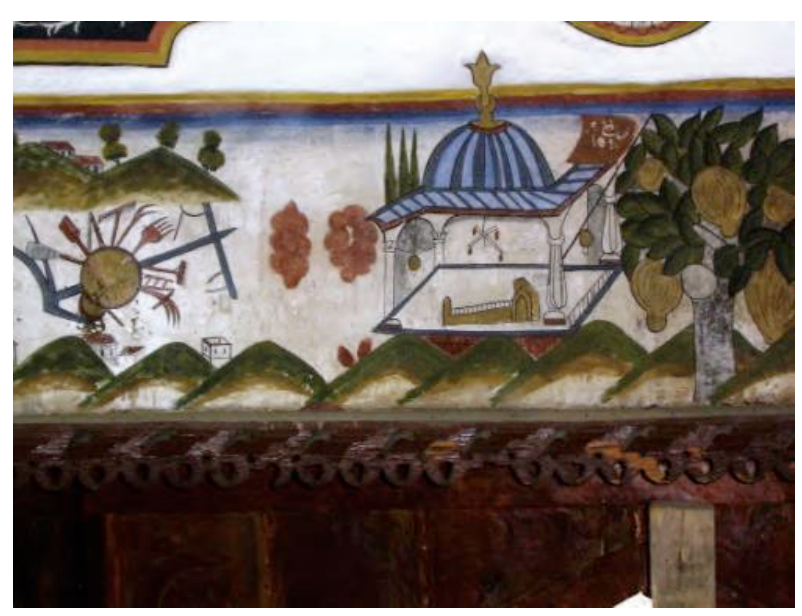

Resim 13: Amasya II. Beyazıd Camii Şadırvanı, baldeken türbe tasviri (Taşkesen 186)

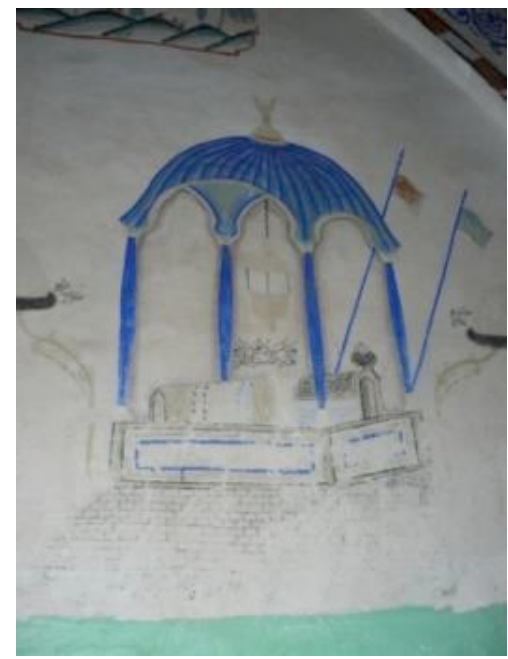

Resim 14: Tokat, Zile, Tekke Köyü Şeyh Nusrettin (Nusrat) Türbesi, doğu duvarında bir baldeken türbe tasviri (Şener 2011:657)

\footnotetext{
${ }^{4}$ Ersel Çağlıtütüncigil, “Türk Süsleme Sanatında Nar: "Form Köken ve İkonografik Anlamı”, Türklük Bilimi Araştırmaları, C.18, S.33, s.68

${ }^{5}$ Rüçhan Arık, Batılılaşma Dönemi Anadolu Tasvir Sanatı, Türkiye İş Bankası Kültür Yayınları, Ankara 1976, s.74.
} 
Kandil ve Perde: 18 ve 19 yüzyıl Avrupa barok etkili Osmanlı duvar resimlerinin vazgeçilmez bir unsuru olan perde tasvirleri, başkent İstanbul'da bulunan sivil yapılarda sık karşımıza çıkan ve genellikle bezeme ve çevreleme amacı taşıyan bir kullanım alanı vardır. Başkent dışında ise genellikle cami mihraplarında kandil ile birlikte görülen kullanımı ise ikonografik olarak oldukça farklıdır. Mihrabın sağında ve solunda birer kanat şeklinde açılmış olarak betimlenen perdenin orta kısmından sarkan kandil şeklinde betimlenir. Bu kompozisyonun ahirete açılan ve bu dünyayı sembolize eden perdeyi geçtikten sonra kandilin nur ile ilişkilendirilmesinden ötürü mihraplarda kullanıldığını düşünmek doğru olur. Bir başka deyişle perdenin bu dünya ile öteki dünyayı ayıran bir simge olduğunu ve ilahi nurun müşahedesi için açılması gereken setri (perdeyi) temsil ettiği şeklinde yorumlanabilir. ${ }^{6}$ Anadolu'da bazı camilerinin mihrap nişlerinin içinde, günlük kullanım eşyalarından olan kandil ve mum tasvirleri de Huzur verici ve uhrevi anlamlarından ötürü sıkça karşımıza çıkmaktadır. Şeyh Halil Türbesi'nde örneğini gördüğümüz kimi kandiller perde ile birlikte tasvir edilir. Bunun benzerlerini ise İzmir Ödemiş Bademli Kılcızade Mehmet A ğa Camii, Aydın Koçarlı Cincin köyü Camii, Denizli Belenardıç (Toraman) Köyü Camii ve Manisa Soma Damgacı Camilerinin mihrap nişlerinde görmek mümkündür (Resim 15-16).

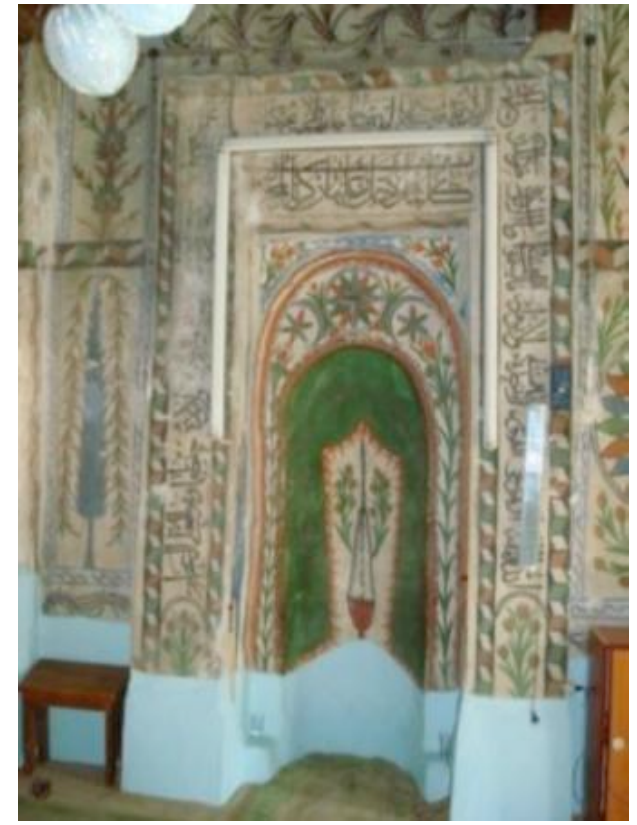

Resim 15: Denizli Belenardıç (Toraman) Köyü Camii, kandil ve perde tasviri (Şener 2011: 559)

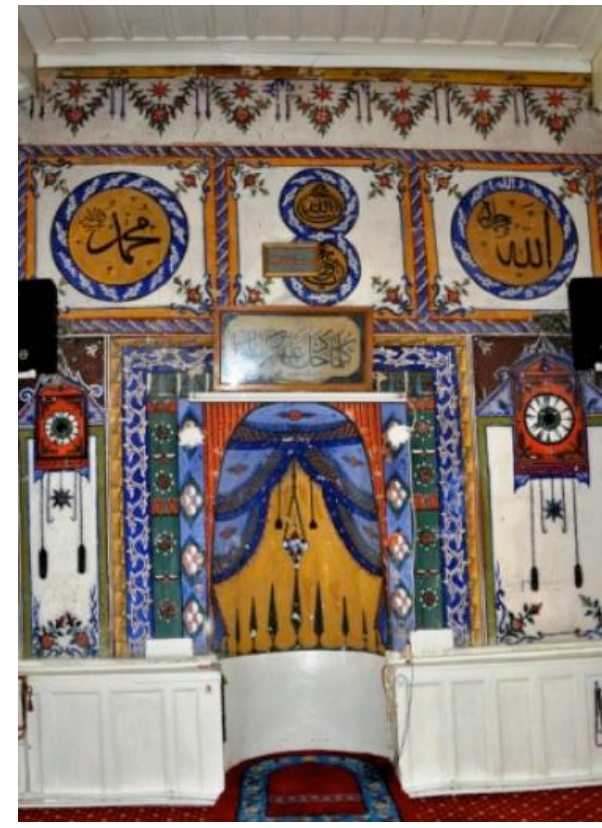

Resim 16: Kırşehir Mucur Emine Hanım Camii, kandil ve perde tasviri (Tali 2013: 523)

Bektaşi ve Mevlevi sikkeleri; Türbenin güney duvarında yer alan Mevlevi ve Bektaşi sikkelerinin bir arada tasvir edilişi örneklerine pek az rastlanan tasvir grubudur. Bu iki başlığın bir arada oluşunu, II. Mahmut döneminde (salt.1808-1839) alınan bir karar ile açıklamak

\footnotetext{
${ }^{6}$ Tarkan Okçuoğlu, 18. ve 19. Yüzyıllarda Osmanlı Duvar Resimlerinde Betimleme Anlayışı, (İstanbul Üniversitesi, Sosyal Bilimler Enstitüsü Arkeoloji ve Sanat Tarihi Bölümü Sanat Tarihi Ana Bilim Dalı, Yayınlanmamış Doktora Tezi), İstanbul 2000, s.51.
}

\section{History Studies}


mümkün olabilir. Söz konusu kararda; 60 yıldan eski Bektaşi tekkeleri ve türbeleri Sünni tarikatlara verilmiş, diğerleri kapatılarak Şeyhleri ve müritleri tashih-i itikad ettirilmek üzere ulema merkezli şehir ve beldelere gönderilmiştir. Bektaşi tekkelerine Nakşibendi, Kadiri ve Saadiye mensuplarının bir çeşit kayyum olarak atandığ 1 ve buralardaki şeyhlerin idam edildiğ $i$ ya da Anadolu'da katı Sünniliğin hakim olduğu şehirlere sürgün edildiği anlaşılmaktadır. Bektaşilere ya da öyle olduğu sanılanlar ve onlarla ilişkileri olanlar takibe alınmış ve sert cezalara çarptırılmışlardır. Tanzimat fermanının getirdiği hoşgörü ortamı ile birlikte özellikle II.Mahmut döneminin aksine din, mezhep ve bilhassa tarikatlara müsaade edildiği görülür. 1852 tarihli bir irade de Hacıbektaş dergahındaki şeyhin durumunun düzeltilip ayrıca dergahın Bektaşilere geri verildiği görülür. Ancak II.Mahmut’tan sonra Bektaşilik yeni bir yaşam tarzı ve ritüel benimseyerek daha çok bir takiye yoluna giderek diğer tarikatlara özellikle Nakşibendiliğe sızmışlardır. ${ }^{7}$ Sivas, Amasya ve Tokat gibi bölgelerde sıklıkla rastlanan Bektaşi tekkelerine devlet tarafindan ve devlete yakın olan Mevlevi şeyhlerinin kayyum olarak atanmış olması ihtimal dahilindedir. Nitekim Sivas Şeyh Halil türbesinde gördüğümüz Mevlevi ve Bektaşi sikkelerinin yan yana betimlenişini bu olaylar sonucunda Mevlevi bir kayyumun bölgeye atandığını düşündürür. Nitekim benzer betimlemelerin yine Amasya Merzifon Kara Mustafa Paşa Cami Şadırvanı Kubbe eteğinde, Tokat Zile Şeyh Nusrettin (Nusrat) Türbesi güney duvarında ve Afyon Başmakçı Recep Bey Caminde yer alması bu düşünceyi güçlendirmektedir (Resim 17-18).

HISTORY STUDIES 1851

Volume 11 Issue 5 October 2019

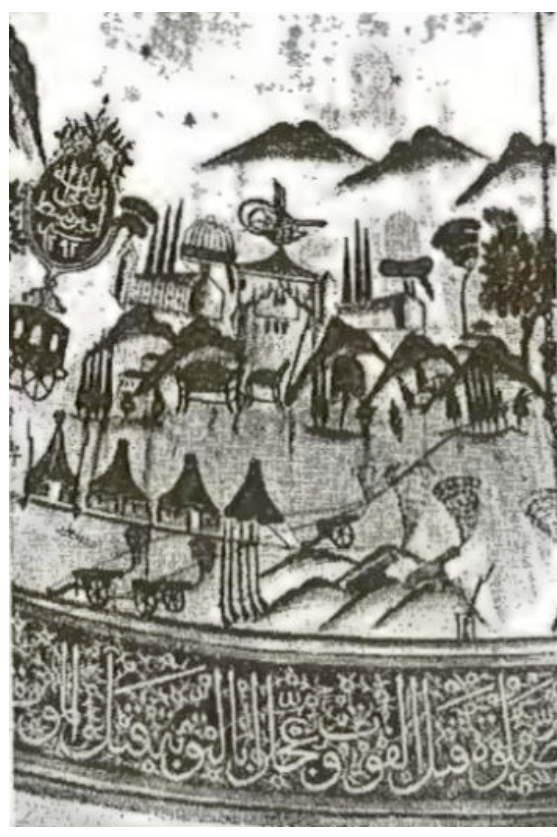

Resim 17: Amasya, Merzifon Kara Mustafa Pașa Camii Şadırvanı (Tanman 1993: 519)

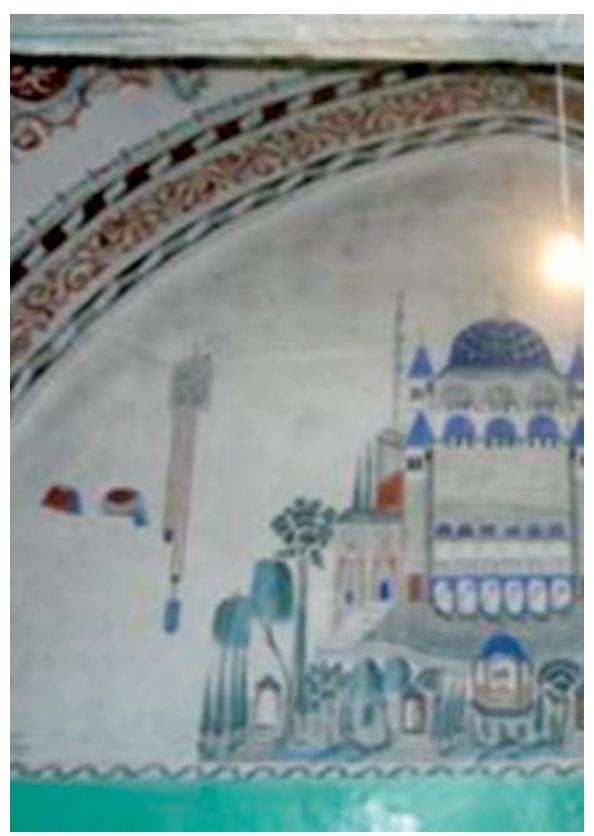

Resim 18: Tokat, Zile Şeyh Nusrettin (Nusrat) Türbesi (Şener 2011: 658).

${ }^{7}$ İlber Ortaylı, “Tarikatlar ve Tanzimat Dönemi Osmanlı Yönetimi”, Otam Dergisi, S.6, Ankara 1995, s.283-287. 
Sekiz dilimli kubbe; Türbenin kubbesinin şemsiye gibi sekiz dilimle ayrıldığ gözlemlenmektedir. Bektaşi sikkelerinin ve yine Bektaşi şeyhlerinin mezar taşlarının biçimleri on iki dilimli oluşu on iki imama gönderme niteliğindedir. Ancak sekiz dilimli tacın görüldüğü mezar taşlarına da rastlamak mümkündür. Üsküdar Karacaahmet, Duvardibi'nde bulunan Şeyh Hacı Hoşgör Ahmed Baba'nın ve Derviş Hasan Ahmed Hoşgör'e ait mezar taşları böyle sekiz dilimli taç şeklindedir. ${ }^{8}$ Kubbe göbeğinde yer alan sekiz köşeli yıldız motifi ise yine Bektaşi geleneğindeki teslim taşına gönderme yapıldığını düşündürmektedir. Teslim taşı Bektaşilikte geleneksel olarak on iki köşeli olup, dervişler bunu boyunlarına ya da kemerlerine asmak suretiyle acz ve teslimiyetlerinin bir ifadesi olarak kullanırlar. Yine Atasoy, teslim taşlarının sekiz köşeli olabileceklerine de değinmektedir. ${ }^{9}$ Dolayısıyla Şeyh Halil türbesinin kubbe göbeğinde bulunan sekiz köşeli yıldızı teslim taşı ile ilişskilendirmek mümkündür.

\section{Sonuç}

Osmanlı duvar resimleri, Osmanlı mimarisinin batı etkisinde olduğu 18. ve 19. yüzyıllarda ortaya çıkmış ve yaygınlaşmıştır. Avrupa'nın barok ve rokoko unsurlarının Osmanlı yorumlu bir yansıması olarak özellikle c ve S kıvrımlı motifler ile dönemin Osmanlı mimarisinde sıkça görülmeye başlanmıştır. Bu motiflerin çevrelediği duvar resimleri bu dönemin bir ürünüdür. Ancak yüzyıllarca neredeyse Osmanlı resim sanatının tek egemen türü olan geleneksel resimli el yazmalarını konu ve üslup olarak devam ettirmezler. Bu yeni anlayış önceleri başkent İstanbul'da daha sonraları imparatorluğun diğer bölgelerinde kendi özgün konularını yaratmıştır. Başkent İstanbul'da daha çok saray, köşk ve kasırlarda görülen duvar resimleri, taşrada bu yapılara ek olarak dini mimari örneklerinde de kendisini göstermektedir. Özellikle Anadolu ve Balkanlarda bulunan 19. Yüzyıl camileri en çok resimlenen yapı türü olmuştur. Başkent İstanbul'da bulunan saray ve köşklerde yaygın natürmort, manzara ve mimari tasvirler, Anadolu camilerinde de görülürken bunlara ek olarak dini ve tasavvufi hayatın sembollerinden oluşan kompozisyonları, endüstri devriminin getirdiği ve Osmanlı hayatına giren kimi araç ve gereçler de dini mimarinin duvarlarında yer bulmuştur.

Dini mimarinin camiler dışındaki türbe, tekke ve muvakkithane gibi diğer örnekleri de resimlenmiştir. Sayıca az olan bu örnekler daha çok Amasya, Tokat ve Sivas gibi merkezlerde görülmektedir. Çalışmanın ana konusunu oluşturan Sivas Şeyh Halil Türbesi bu az sayıdaki örneklerden birisidir. Yapının duvarlarında görülen resimler çağdaşı diğer yapılarda olduğu gibi mimari, bitkisel, dini/tasavvufi, natürmort gibi konulardan oluşur ancak yukarıda da söz edildiği gibi devrinin kimi olaylarına gönderme yapan tasvirleri ile ayrı bir öneme sahiptir. Sanatçısına dair bir imzanın yer almadığı resimlerde bölge de etkin olan Zileli Emin ve Nakkaş İbrahim'in üslupları ile uyuşmamaktadır. Bu nedenle resimler bölgede dolaşan başka bir halk sanatçısına ait olduğu söylenebilir

\section{KAYNAKÇA}

ARIK, Rüçhan, Batılılaşma Dönemi Anadolu Tasvir Sanatı, Türkiye İş Bankası Kültür Yayınları, Ankara 1976.

ATASOY, Nurhan, Derviş Çeyizi Türkiye'de Tarikat Giyim Kuşam Tarihi, Kültür ve Turizm Bakanlığı Yayınları, İstanbul 2006.

ARIK Rüçhan- Mehmet Oluş, Erken Devir Anadolu-Türk Mimarisinde Türbe Biçimleri, Türk Tarih Kurumu Yayınları, Ankara 1969.

\footnotetext{
${ }^{8}$ Nurhan Atasoy, Derviş Çeyizi Türkiye'de Tarikat Giyim Kuşam Tarihi, Kültür ve Türizm Bakanlığı Yayınları, İstanbul 2006, s.140.

${ }^{9}$ Atasoy, a.g.e., s.248.
} 
ALKAN, Mustafa, "Hacı Bektaş- Velî Tekkesine Nakşibendî Bir Şeyhin Tayini: Merkezî Bir Dayatma ve Sosyal Tepki”, Türk Kültürü ve Hacı Bektaş Veli Araştırma Dergisi, C.57, 2011, s.213-223.

AKSEL, Malik, Türklerde Dini Resimler, Kap1 Yayınları, İstanbul 2015.

BIRGE, John Kingsley, Bektaşilik Tarihi, Çev: Reha Çamuroğlu, Ant Yayınları, İstanbul 1991.

ÇAL, Halit. "Tokat Zile Yeşilce Köyü Şeyh Eylük Türbesi,” Prof. Dr. Yılmaz Önge Armağanı, Selçuklu Araştırmaları Merkezi Yayını, Konya 1993, s.293-305.

ÇAL, Halit. "Şeyh Nasreddin (Nusret) Türbesi," Türk Tarihinde ve Kültüründe Tokat Sempozyumu (2-6 Teтmuz 1986) Bildiriler Kitabı, Ankara 1987, s.427-461.

ÇAĞLITÜTÜNCİGIL, Ersel, "Türk Süsleme Sanatında Nar: "Form Köken ve İkonografik Anlamı" Türklük Bilimi Araştırmaları, C.18, S.33, 2013, s.61-91.

DURAN, Remzi, "Seki-Tekke Camii ve Tekke Sanatı ile İlgisi Üzerine", Dokuz Eylül Üniversitesi İlahiyat Fakültesi Dergisi, C.7, 1992, s.323-349.

HAKKI, Acun, "Sivas ve Çevresindeki Eski Eserlerin Listesi ve Turistik Değerleri" Vakıflar Dergisi, C.20, 1988, s.183-220.

KARAMAĞARALI, Beyhan, "Anadolu'da XII-XVI Asırlardaki Tarikat ve Tekke Sanatı Hakkında”, Ankara Üniversitesi İlahiyat Fakültesi Dergisi, C.21, 1976, s.247-276.

KALAFAT, Yaşar, "Diyanet İşleri Başkanlığı Arşivine Göre Horasan Eri Olarak Bilinen Anadolu Yatırları I", Ankara Üniversitesi İlahiyat Fakültesi Dergisi, C.40, 1966, s.511535.

KAYA, Doğan, "Sivas’ta Yatmakta Olan Horasan Merkezli Anadolu Erleri". Halkbilim Araştırmaları. Kitabevi Yayınları, İstanbul 2002, s.261-85.

ORTAYLI, İlber, "Tarikatlar ve Tanzimat Dönemi Osmanlı Yönetimi”, Otam Dergisi, S.6, Ankara 1995, s.281-287.

OKÇUOĞLU, Tarkan, 18. ve 19. Yüzyllarda Osmanlı Duvar Resimlerinde Betimleme Anlayışı, (İstanbul Üniversitesi, Sosyal Bilimler Enstitüsü Arkeoloji ve Sanat Tarihi Bölümü Sanat Tarihi Ana Bilim Dalı, Yayımlanmamıș Doktora Tezi), İstanbul 2000.

RENDA, Günsel, Batılılaşma Döneminde Türk Resim Sanatı, Türk Tarih Kurumu Basımevi, Ankara 1977.

ŞENER, Dilek, 18.ve 19.yüzyıllarda Anadolu'da Duvar Resimleri, (Ankara Üniversitesi, Sosyal Bilimler Enstitüsü Sanat Tarihi Anabilim Dalı, Yayımlanmamış Doktora Tezi), Ankara 2011.

TALİ, Şerife, ““'Kırşehir/Mucur'daki Hüseyin Ağa Camii ile Emine Hanım Camii’nin Kalemişleri”, Uluslararası Sosyal Araştırmalar Dergisi, C.6, S.25, 2013, s.504528.

TANMAN, Baha. "Merzifon Kara Mustafa Paşa Camii Kubbesinde Zileli Emin'in yarattığı Osmanlı Dünyası ve Bu Dünyaya Yansıyan Kişiliği”, Sanat Tarihinde İkonografik Araştırmalar, Güner İnal'a Armağan, Hacettepe Üniversitesi Yayınları, Ankara 1993, s.491-521.

UZ TAŞKESEN, Ayşe Nermin. "Amasya II. Beyazıt Camisi Şadırvanı Duvar Resimlerinin Restorasyonu ve İkonografik Çözümlemesi”. Vaklflar Dergisi, S. 35, 2011, s. 177-190.

\section{History Studies}

